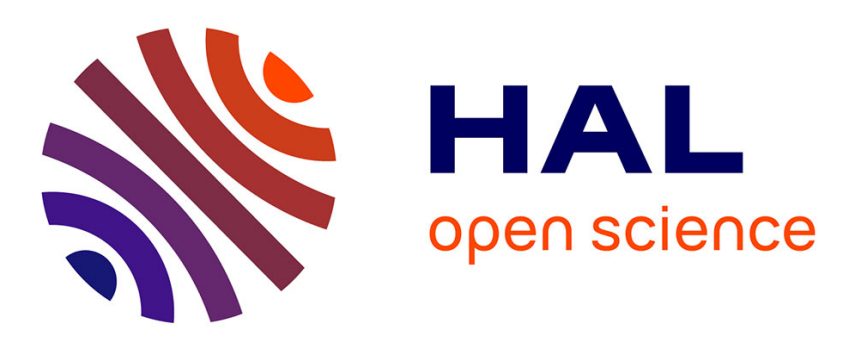

\title{
A computational study of solution equilibria of platinum-based ethylene hydroamination catalytic species including solvation and counterion effects: Proper treatment of the free energy of solvation
}

Pavel Dub, Rinaldo Poli

\section{To cite this version:}

Pavel Dub, Rinaldo Poli. A computational study of solution equilibria of platinum-based ethylene hydroamination catalytic species including solvation and counterion effects: Proper treatment of the free energy of solvation. Journal of Molecular Catalysis A: Chemical, 2010, 324 (1-2), pp.89-96. 10.1016/j.molcata.2010.03.003 . hal-03177797

\section{HAL Id: hal-03177797 \\ https://hal.science/hal-03177797}

Submitted on 23 Mar 2021

HAL is a multi-disciplinary open access archive for the deposit and dissemination of scientific research documents, whether they are published or not. The documents may come from teaching and research institutions in France or abroad, or from public or private research centers.
L'archive ouverte pluridisciplinaire HAL, est destinée au dépôt et à la diffusion de documents scientifiques de niveau recherche, publiés ou non, émanant des établissements d'enseignement et de recherche français ou étrangers, des laboratoires publics ou privés. 


\section{A computational study of solution equilibria of platinum-based ethylene hydroamination catalytic species including solvation and counterion effects: proper treatment of the free energy of solvation}

Pavel A. Dub ${ }^{\mathrm{a}, \mathrm{b}}$ and Rinaldo Poli $*, \mathrm{a}, \mathrm{c}$

${ }^{a}$ CNRS; LCC (Laboratoire de Chimie de Coordination); Université de Toulouse; UPS, INP; F31077 Toulouse, France ; 205, route de Narbonne, F-31077 Toulouse, France; Fax: (+) 33561553003; E-mail: poli@lcc-toulouse.fr

${ }^{b}$ A. N. Nesmeyanov Institute of Organoelement Compounds, Russian Academy of Sciences, Vavilov Street 26, 119991 Moscow, Russia

${ }^{c}$ Institut Universitaire de France, 103, bd Saint-Michel, 75005 Paris, France 


\section{Summary}

A DFT/B3LYP study of the effect of the explicit inclusion of the $\mathrm{Me}_{4} \mathrm{P}^{+}$cation (as a model of $n \mathrm{Bu}_{4} \mathrm{P}^{+}$) on the calculation of solution equilibria involving anionic $\mathrm{Pt}^{\mathrm{II}}$ complexes is reported. The calculated complexes are models of species that potentially participate in the low-energy portion of the catalytic cycle of the ethylene hydroamination by aniline catalyzed by the $\mathrm{PtBr}_{2} /\left(n \mathrm{Bu}_{4} \mathrm{P}\right) \mathrm{Br} \quad$ system, namely $\left.\quad\left(n \mathrm{Bu}_{4} \mathrm{P}\right)_{2}\left[\mathrm{PtBr}_{4}\right] \quad(\mathbf{1}), \quad\left(n \mathrm{Bu}_{4} \mathrm{P}\right)_{2}\left[\mathrm{Pt}_{2} \mathrm{Br}_{6}\right] \quad(\mathbf{1})^{\prime}\right)$ $\left(n \mathrm{Bu}_{4} \mathrm{P}\right)\left[\mathrm{PtBr}_{3}\left(\mathrm{C}_{2} \mathrm{H}_{4}\right)\right] \quad(2), \quad\left(n \mathrm{Bu}_{4} \mathrm{P}\right)\left[\mathrm{PtBr}_{3}\left(\mathrm{PhNH}_{2}\right)\right] \quad$ (3), trans-[ $\left.\mathrm{PtBr}_{2}\left(\mathrm{C}_{2} \mathrm{H}_{4}\right)\left(\mathrm{PhNH}_{2}\right)\right]$ (4), cis$\left[\mathrm{PtBr}_{2}\left(\mathrm{C}_{2} \mathrm{H}_{4}\right)\left(\mathrm{PhNH}_{2}\right)\right] \quad$ (5), cis- $\left[\mathrm{PtBr}_{2}\left(\mathrm{PhNH}_{2}\right)_{2}\right] \quad$ (6), trans- $\left[\mathrm{PtBr}_{2}\left(\mathrm{C}_{2} \mathrm{H}_{4}\right)_{2}\right] \quad$ (7), and cis$\left[\mathrm{PtBr}_{2}\left(\mathrm{C}_{2} \mathrm{H}_{4}\right)_{2}\right](\mathbf{8})$. The relative energies are based on gas-phase geometry optimizations followed by C-PCM calculations of the solvation effects in dichloromethane and aniline at $25^{\circ} \mathrm{C}$ and $150^{\circ} \mathrm{C}$. Three different approaches have been considered to describe the relative energies in solution: $\Delta \mathrm{E}^{\mathrm{CPCM}}\left(\Delta \mathrm{E}_{\mathrm{el}}{ }^{\text {gas }}+\Delta \Delta \mathrm{G}^{\text {solv }}\right), \Delta \mathrm{G}_{\mathrm{v}}{ }^{\mathrm{CPCM}}\left(\Delta \mathrm{E}_{\mathrm{el}}{ }^{\text {gas }}+\Delta \mathrm{E}_{\mathrm{ZPVE}}{ }^{\text {gas }}+\Delta \mathrm{E}_{\mathrm{v}}{ }^{\text {gas }}-\mathrm{T} \Delta \mathrm{S}_{\mathrm{v}}{ }^{\text {gas }}+\Delta \Delta \mathrm{G}^{\text {solv }}\right)$ and $\Delta \mathrm{G}^{\mathrm{CPCM}}\left(\Delta \mathrm{H}^{\mathrm{gas}}-\mathrm{T} \Delta \mathrm{S}^{\text {gas }}+\Delta \Delta \mathrm{G}^{\text {solv }}\right)$, where $\Delta \mathrm{E}_{\mathrm{v}}{ }^{\text {gas }}$ and $\Delta \mathrm{S}_{\mathrm{v}}$ gas includes only the vibrational contribution and $\Delta \Delta \mathrm{G}^{\text {solv }}$ for each compound is the solvation free energy resulting from the CPCM calculation. The cation-anion association was found favourable in both solvents at the $\Delta \mathrm{E}^{\mathrm{CPCM}}$ and $\Delta \mathrm{G}_{\mathrm{v}}{ }^{\mathrm{CPCM}}$ levels, but nearly neutral at the $\Delta \mathrm{G}^{\mathrm{CPCM}}$ level. Consideration of the associated salts has a drastic effect on the energy scheme but significantly changes the relative energies only when doubly charged complexes are involved. The energy changes for equilibria that involve only neutral of singly charged species are not greatly affected by the cation inclusion. The $\Delta \mathrm{G}^{\mathrm{CPCM}}$ approach provides results in greater agreement with the available equilibrium data.

Keywords: platinum, catalytic hydroamination, aniline complexes, solvent models, DFT calculations, counterion effect 


\section{Introduction}

Brunet and co-workers have unveiled in 2004 a simple and efficient catalyst - one of the most performing reported to date - for the intermolecular hydroamination of ethylene and higher olefins by anilines, which consists of ligandless $\mathrm{PtBr}_{2}$ activated by $n \mathrm{Bu} 4 \mathrm{PBr}$ [1-4]. A mechanism involving olefin activation followed by amine nucleophilic addition (as opposed to amine activation followed by olefin coordination and insertion) seems operative for this platinum catalyst [4] on the basis of a previous computational study on the $\left[\mathrm{PtCl}\left(\mathrm{C}_{2} \mathrm{H}_{4}\right)\left(\mathrm{PH}_{3}\right)_{2}\right]^{+}$model [5] and of the known stoichiometric reactivity of Pt-(olefin) complexes with amines [6-12]. However, the previous computational study addresses only models of phosphine-containing complexes, whereas the Brunet catalyst was found to be poisoned by phosphine ligands [1] while it is activated by halide anions (bromide being the best). Therefore, we set out to investigate the mechanistic details of this catalytic system both experimentally and computationally.

We have recently reported the synthesis and characterization of a variety of complexes formed by $\mathrm{PtBr}_{2}$ in the presence of the activator $\left(\mathrm{Br}^{-}\right)$and substrates (ethylene, aniline) and a preliminary DFT investigation of their relative stability [13]. Thus, complexes $\left(n \mathrm{Bu}_{4} \mathrm{P}\right)_{2}\left[\mathrm{PtBr}_{4}\right]$ (1), $\quad\left(n \mathrm{Bu}_{4} \mathrm{P}\right)_{2}\left[\mathrm{Pt}_{2} \mathrm{Br}_{6}\right] \quad\left(\mathbf{1}^{\prime}\right), \quad\left(n \mathrm{Bu}_{4} \mathrm{P}\right)\left[\mathrm{PtBr}_{3}\left(\mathrm{C}_{2} \mathrm{H}_{4}\right)\right] \quad(\mathbf{2}), \quad\left(n \mathrm{Bu}_{4} \mathrm{P}\right)\left[\mathrm{PtBr}_{3}\left(\mathrm{PhNH}_{2}\right)\right] \quad(\mathbf{3}), \quad$ trans[PtBr $\left.2\left(\mathrm{C}_{2} \mathrm{H}_{4}\right)\left(\mathrm{PhNH}_{2}\right)\right](4)$, cis- $\left[\mathrm{PtBr}_{2}\left(\mathrm{C}_{2} \mathrm{H}_{4}\right)\left(\mathrm{PhNH}_{2}\right)\right](5)$, and cis- $\left[\mathrm{PtBr}_{2}\left(\mathrm{PhNH}_{2}\right)_{2}\right](6)$ have been isolated and fully characterized. Complexes trans- $\left[\mathrm{PtBr}_{2}\left(\mathrm{C}_{2} \mathrm{H}_{4}\right)_{2}\right](7)$ and cis- $\left[\mathrm{PtBr}_{2}\left(\mathrm{C}_{2} \mathrm{H}_{4}\right)_{2}\right](\mathbf{8})$, although not synthesized, could also potentially be implicated as intermediates or off-loop catalytic species, since our preliminary DFT calculations show that they are energetically accessible by ligand exchange from $\left[\mathrm{PtBr}_{3}\left(\mathrm{C}_{2} \mathrm{H}_{4}\right)\right]^{-}$and $\mathrm{C}_{2} \mathrm{H}_{4}$. It should also be mentioned that the related chlorido complexes, cis and trans $\left[\mathrm{PtCl}_{2}\left(\mathrm{C}_{2} \mathrm{H}_{4}\right)_{2}\right]$, have been reported by other authors [14-16].

The experimental studies of the solution equilibria (in a variety of solvents at room temperature) backed up by the DFT study indicated that complex $\left[\mathrm{PtBr}_{3}\left(\mathrm{C}_{2} \mathrm{H}_{4}\right)\right]^{-}$is the most 
stable species and that all other complexes mentioned above are thermally accessible by simple ligand exchange. Scheme 1 shows the relationship between all these different complexes. A roman numeral is used to describe the complexes in solution, corresponding to the Arabic number of the isolated compounds. While this may seem redundant for the neutral compounds, it is important to distinguish the free complexes in solution from the isolated compounds in the case of charged species (e.g.: $\mathbf{1}$ is the $n \mathrm{Bu}_{4} \mathrm{P}^{+}$salt of the dianion $\left.\mathbf{I}\right)$. All the ethylene containing complexes - II, IV, V, VII and VIII - are therefore potential candidates for aniline nucleophilic addition.

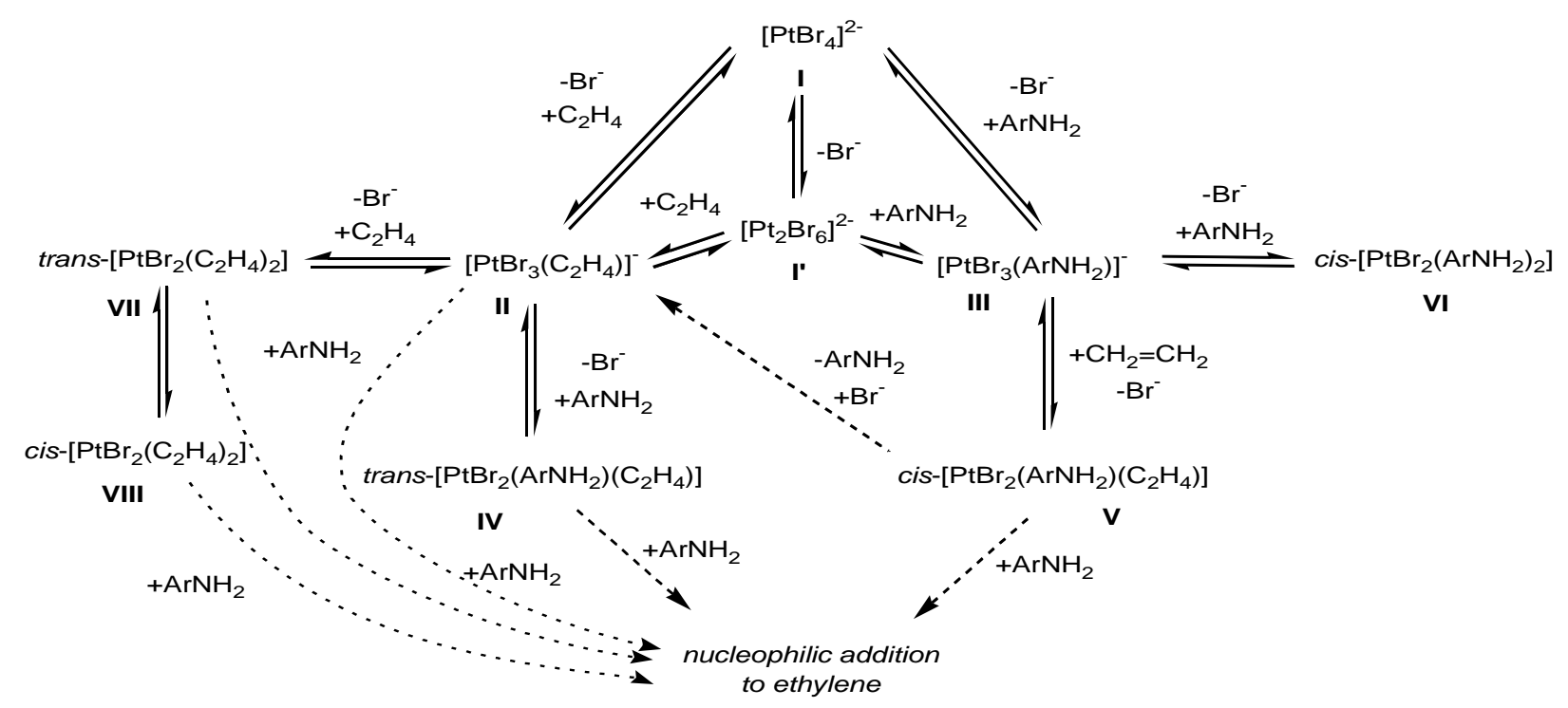

Scheme 1

The above mentioned theoretical calculations were performed without consideration of the counterion for the anionic species, using the B3LYP functional and applying the C-PCM model $[17,18]$ on the gas-phase optimized geometries. The solution behaviour was described on the basis of the $\Delta \mathrm{G}^{\mathrm{CPCM}}$ parameter $\left(\Delta \mathrm{H}^{\mathrm{gas}}-\mathrm{T} \Delta \mathrm{S}^{\mathrm{gas}}+\Delta \Delta \mathrm{G}^{\text {solv }}\right)$ [19], which gave results in qualitative agreement with the experimental equilibrium studies [13]. $\Delta \Delta \mathrm{G}^{\text {solv }}$ is the difference between the solvation free energy corrective terms for the products and the reactants. There are questions, however, related to the partial quenching of translational and rotational modes, as well as the 
(PV) term, upon going from the gas phase to a condensed state. The problem of the accurate calculation of enthalpies and entropies in solution is a major computational challenge and no universal solution is apparently available [20-22]. A very common approach to the computational study of solution energetics involves the complete neglect of the gas phase thermochemical parameters $\left(\Delta \mathrm{E}^{\mathrm{CPCM}}=\Delta \mathrm{E}_{\mathrm{el}}^{\text {gas }}+\Delta \Delta \mathrm{G}^{\text {solv }}\right)$, as this term is directly reported in the Gaussian output, but it should be noted that this approach mixes an electronic energy term with a free energy term and the result has no clear physical meaning. Another approach is based on the neglect of only the translational and rotational components of the gas phase entropy term $\left(\Delta \mathrm{H}^{\text {gas }}-\right.$ $\left.\mathrm{T} \Delta \mathrm{S}_{\mathrm{v}}{ }^{\text {gas }}+\Delta \Delta \mathrm{G}^{\text {solv }}\right)$, where $\Delta \mathrm{S}_{\mathrm{v}}{ }^{\text {gas }}$ represent the vibrational component of the entropy change for the system optimized in the gas phase [23]. Note, however, that this term has also no precise relevance, because if we assume complete quenching of the translational and rotational components of the molecular motions upon going from the gas phase to the solution, then the translational and rotational components of the overall partition function should be removed. That is, the translational and rotational contributions to the thermal energy should also be neglected, as well as the PV term, not only the translational and rotational contributions to the entropic term. Note that equalizing enthalpy and energy in condensed phases is a common approximation. In this paper, we shall define a vibrational-only reaction free energy in solution, $\Delta \mathrm{G}_{\mathrm{v}}{ }^{\mathrm{CPCM}}=$ $\Delta \mathrm{E}_{\mathrm{el}^{\mathrm{gas}}}+\Delta \mathrm{E}_{\mathrm{ZPVE}}{ }^{\mathrm{gas}}+\Delta \mathrm{E}_{\mathrm{v}}{ }^{\mathrm{gas}}-\mathrm{T} \Delta \mathrm{S}_{\mathrm{v}}{ }^{\text {gas }}+\Delta \Delta \mathrm{G}^{\text {solv }}$, where the gas phase electronic energy term of the reaction, $\Delta \mathrm{E}_{\mathrm{el}}{ }^{\text {gas }}$, is only corrected by the $\mathrm{ZPVE}$ term, $\Delta \mathrm{E}_{\mathrm{ZPVE}}{ }^{\text {gas }}$, by the thermal vibrational contribution to the energy, $\Delta \mathrm{E}_{\mathrm{v}}{ }^{\text {gas }}$, by the vibrational entropic contribution, $-\mathrm{T} \Delta \mathrm{S}_{\mathrm{v}}{ }^{\mathrm{gas}}$, and by the solvation free energy corrective term, $\Delta \Delta \mathrm{G}^{\text {solv }}$. A general problem is also the use of gas-phase frequencies for the calculation of the thermochemical parameters, because solution-phase optimizations are often haunted by several convergence problems. Another complication in our system, however, is the energetic effect of cation-anion association (ion pairing). Salts are generally present in solutions of low dielectric constant solvents as associated species, which 
may be energetically stabilized not only by Coulombic forces but also be specific non covalent interactions (i.e. hydrogen bonds).

We have therefore wondered how the agreement of the above mentioned different energy approaches $\left(\Delta \mathrm{E}^{\mathrm{CPCM}}, \Delta \mathrm{G}_{\mathrm{v}}{ }^{\mathrm{CPCM}}\right.$ and $\left.\Delta \mathrm{G}^{\mathrm{CPCM}}\right)$ would change after inclusion of the counterion in the calculations. The present contribution reports new theoretical studies (DFT/B3LYP) of the ionic complexes of Scheme 1 (I, I', II and III) after inclusion of the cation, and new considerations on the agreement of the above mentioned approaches to the description of the solution equilibria involving species I-VIII.

\section{Computational methods}

All geometry optimizations were performed with the Gaussian03 suite of programs [24] using the B3LYP functional which includes the three-parameter gradient-corrected exchange functional of Becke [25] and the correlation functional of Lee, Yang, and Parr which includes both local and non-local terms [26, 27]. In spite of several problems such as the underestimation of barrier heights, inaccuracy to describe weak interactions and overestimation of spin polarization, this functional was selected because it remains one of the most popular functionals used in transition metal computational chemistry [28]. In addition, all molecules described in this work are diamagnetic and the paramagnetic excited states are expected to be at much higher energy, thus the RHF description is appropriate. The basis set chosen was the standard 6-31+G*, which includes both polarization and diffuse functions that are necessary to allow angular and radial flexibility to the highly anionic systems, for all atoms of type $\mathrm{H}, \mathrm{C}, \mathrm{N}, \mathrm{P}$ and $\mathrm{Br}$. The $\mathrm{Pt}$ atom was described by the LANL2TZ(f) basis, which is an uncontracted version of LANL2DZ and includes an f polarization function and an ECP [29]. The starting geometries for the calculations were those previously optimized for the free ion, after introduction of the cations at reasonable distances. Several relative positions of the cation and anion were used as input geometry in each case, and only the lower energy one in solution is reported (the others were 
generally very close in energy, typically at $<1 \mathrm{kcal} \mathrm{mol}^{-1}$ from the most stable structure). Stability tests carried out on several molecules with the Gaussian03 default options showed stable wavefunctions in all cases. Frequency calculations were carried out for all optimized geometries in order to verify their nature as local minima and for the calculation of thermodynamic parameters at $298.15 \mathrm{~K}$ and at $423.15 \mathrm{~K}$ under the gas-phase and harmonic approximations. For the calculation of $\mathrm{G}_{\mathrm{V}}{ }^{\mathrm{CPCM}}$ of each compound (equal to $\mathrm{E}_{\mathrm{el}}{ }^{\text {gas }}+\mathrm{E}_{\mathrm{ZPVE}}{ }^{\text {gas }+}$ $\left.\mathrm{E}_{\mathrm{v}}{ }^{\mathrm{gas}}-\mathrm{TS}_{\mathrm{v}}{ }^{\mathrm{gas}}+\Delta \mathrm{G}_{\mathrm{solv}}{ }^{\mathrm{CPCM}}\right)$, the $\left(\mathrm{E}_{\mathrm{el}}^{\mathrm{gas}}+\mathrm{E}_{\mathrm{ZPVE}^{\mathrm{gas}}+} \mathrm{E}_{\mathrm{v}}^{\mathrm{gas}}\right)$ term was obtained as $\left[\mathrm{H}^{\mathrm{gas}}(\mathrm{T})-3.5 \mathrm{RT}\right]$ [30], whereas the $\mathrm{S}_{\mathrm{v}}{ }^{\text {gas }}$ term was read directly from the Gaussian output.

Solvent effects were included by means of C-PCM single point calculations on the gasphase optimized geometries $[17,18]$. Among various continuum solvent models, the C-PCM was selected because of its generally better performance [31-33], even though there remains an inherent error when working with charged species [31]. The solvent cavity is created by a series of overlapping spheres by the default UA0 model and all standard settings as implemented in Gaussian03 were used for the C-PCM calculations. Selected calculations have also been carried out with the IEF-PCM model [34-38] (see Results and Discussion section). The reaction freeenergy changes in solution were corrected for the change of standard state from the gas phase (1 atm) to solution (1 M) [39].

\section{Results and discussion}

\section{(a) Gas phase geometries}

Compounds $\mathbf{1}, \mathbf{2}$ and $\mathbf{3}$ were modelled by simplifying the $n \mathrm{Bu}_{4} \mathrm{P}^{+}$cation to the smaller $\mathrm{PMe}_{4}{ }^{+}(\mathrm{TMP})$, yielding systems $(\mathrm{TMP})_{2} \mathbf{I},(\mathrm{TMP}) \mathbf{I I}$ and (TMP)III. The dianion $\left[\mathrm{Pt}_{2} \mathrm{Br}_{6}\right]^{2-}\left(\mathbf{I}^{\prime}\right)$ does not participate in the catalytic cycle. However, it was experimentally found to result from the slow transformation $\left(25^{\circ} \mathrm{C}\right)$ of $\mathbf{I}$ in the absence of free bromide. Therefore, calculations on 
$(\mathrm{TMP})_{2} \mathbf{I}$ ' were also carried out for comparison. For all the neutral complexes (IV-VIII) the geometries were already optimized in our previous study at the same level of theory [13].

The gas phase optimized geometries of $(\mathrm{TMP})_{2} \mathbf{I}$, (TMP) $)_{2} \mathbf{I}$, (TMP)II, (TMP)III, and (TMP)Br are shown in Figure 1. In general the addition of the cation does not significantly affect the geometry of the anionic complex, except for a minor Pt-Br bond shortening for I, I', and the two $\mathrm{Pt}-\mathrm{Br}$ bonds trans to each other in II and III, whereas the unique Pt-Br bond (trans to $\mathrm{C}_{2} \mathrm{H}_{4}$ in II and to $\mathrm{PhNH}_{2}$ in III) slightly lengthens (comparisons are shown in SI). In addition, while free $\mathbf{I}$ ' is planar, a slight bend across the $\mathrm{Br}_{b r} \cdots \mathrm{Br}_{b r}$ edge occurs for the geometry optimized in the presence of the two $\mathrm{PMe}_{4}^{+}$cations. This is certainly caused by the slightly asymmetric positioning of the two cations on the opposite sides of the dianion (see Figure 1) and by the soft nature of the potential energy surface along this bending mode, as shown by the low frequencies of 13 and $33 \mathrm{~cm}^{-1}$ where this molecular motion participates (vibrationally coupled with cation modes).
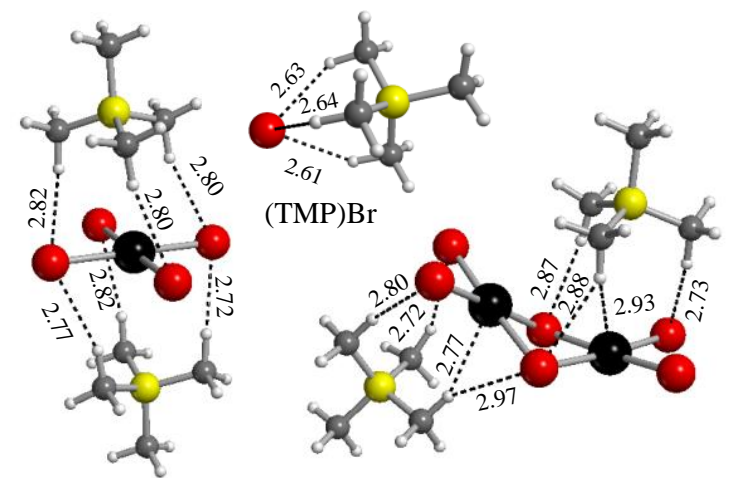

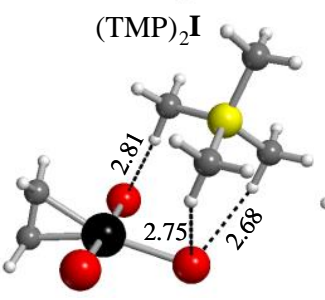

(TMP)II
$(\mathrm{TMP})_{2} \mathbf{I}^{\prime}$

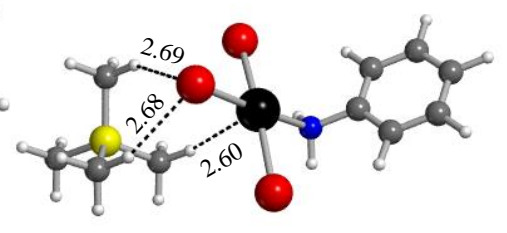

(TMP)III

Figure 1. Optimized geometries of the ion pairs used in this study. The closer cation-anion contacts are highlighted by dotted lines with the distances reported in Ångstroms. 
The cation-anion interactions are established through hydrogen bonds between the methyl $\mathrm{C}-\mathrm{H}$ bonds as proton donors and the bromide anion or the bromido ligands for all the anionic complexes as proton acceptors. These are relatively weak interactions (the shortest $\mathrm{H} \cdots \mathrm{Br}$ distances are ca. $2.61 \AA$ A). For compounds $(\mathrm{TMP})_{2} \mathbf{I}$ ' and (TMP)III, short interactions with the metal center $(\mathrm{C}-\mathrm{H} \cdots \mathrm{Pt})$ were also observed. A comparison of the normal modes in the presence and absence of the cation reveals a correlation between the frequency shift and the bond length changes, with the greater shift $\left(18 \mathrm{~cm}^{-1}\right.$ to higher frequency) being observed for the $E_{\mathrm{u}}$ out-ofphase $\mathrm{Br}-\mathrm{Pt}-\mathrm{Br}$ stretching vibration in $\mathbf{I}$. Certain $\mathrm{Pt}-\mathrm{Br}$ stretching modes also reveal vibrational coupling with the cation vibrations. The cation effect on the calculated frequencies has also been analyzed in a recent contribution for the $\mathrm{Me}_{3} \mathrm{SiO}^{-} \mathrm{K}^{+}$salt [40]. The extrapolation of these results to the real $n \mathrm{Bu}_{4} \mathrm{P}^{+}$salts clearly involves approximations related to the steric and inductive effects of the $n \mathrm{Bu}$ group and to the possibility that other $\mathrm{C}-\mathrm{H}$ bonds of the $n \mathrm{Bu}$ chains also participate in the cation-anion interactions. It is likely that the $n \mathrm{Bu}_{4} \mathrm{P}^{+}$cation also interacts with the anion through the $\alpha \mathrm{C}-\mathrm{H}$ bonds, since these should have the greater acidic character being closer to the positively charged $\mathrm{P}$ atom.

\section{(b) Ion pairing energies}

Since the equilibrium studies reported in our previous contribution [13] were carried out in dichloromethane at room temperature, the C-PCM calculations were also carried out in this solvent, as single point calculations on the gas-phase optimized geometries. An approximation is related to use of this procedure, since the best geometry could in principle change upon going from the gas phase to a condensed phase. However, a recent test carried our in our group for ion pairs of type $\left[\mathrm{Cp} * \mathrm{Mo}\left(\mathrm{PMe}_{3}\right)_{2}(\mathrm{CO}) \mathrm{H}_{2}\right]^{+}\left[\mathrm{BF}_{4}\right]^{-}$has shown insignificant changes when the geometry was reoptimized with the C-PCM in either THF or dichloromethane. The internal geometries of the ions were practically unaffected, whereas the cation-anion interactions became slightly looser, but the effect on the energy was in each case below $0.2 \mathrm{kcal} \mathrm{mol}^{-1}$ relative to the 
corresponding fixed-point C-PCM calculations on the gas-phase optimized geometries [41]. Considering also the convergence problems that are frequently associated with the geometry optimizations in the presence of a C-PCM, we opted to use only the gas-phase optimized geometries. The thermal and entropy corrections to the gas phase electronic energies were done at $298.15 \mathrm{~K}$ to allow comparison with the experiment. C-PCM calculations were also run in aniline at $298.15 \mathrm{~K}$ and at $423.15 \mathrm{~K}$. These cannot be compared with experimental results, but are useful for prediction purposes because the catalytic experiments are run in aniline at $150^{\circ} \mathrm{C}$. Therefore, they are only provided in the Supporting Information. Calculations of solvation free energies on specific neutral, cationic and anionic species were also carried out with the IEF-PCM model (see Table 1). These showed very small changes, $<0.5 \mathrm{kcal} \mathrm{mol}^{-1}$ in most cases, with the notable exception of the $\mathrm{PMe}_{4}{ }^{+} \mathrm{Br}^{-}$ion pair (difference of ca. $1 \mathrm{kcal} \mathrm{mol}^{-1}$ ). The combination of these solvation energy changes for reactants and products in the ion pairing (equation 1) and ligand exchange (equation 7) processes described later yields only minimal energy effects $(<1$ kcal mol ${ }^{-1}$ under all three approaches, $\Delta \mathrm{E}^{\mathrm{CPCM}}, \Delta \mathrm{G}_{\mathrm{v}}{ }^{\mathrm{CPCM}}$ or $\left.\Delta \mathrm{G}^{\mathrm{CPCM}}\right)$.

Table 1. Solvation free energies for selected species in $\mathrm{CH}_{2} \mathrm{Cl}_{2}$ at $298.15 \mathrm{~K}$ under different continuum model approaches.

\begin{tabular}{|l|c|c|}
\hline Species & $\Delta \mathrm{G}_{\text {solv }}{ }^{\mathrm{CPCM}}, \mathrm{kcal} \mathrm{mol}^{-1}$ & $\Delta \mathrm{G}_{\text {solv }}^{\text {IEFPCM }}, \mathrm{kcal} \mathrm{mol}^{-1}$ \\
\hline $\mathrm{PMe}_{4}{ }^{+}$ & -37.16 & -36.88 \\
\hline $\mathrm{C}_{2} \mathrm{H}_{4}$ & 1.79 & 1.88 \\
\hline $\mathrm{PMe}_{4}{ }^{+} \mathrm{Br}^{-}$ & -16.25 & -15.21 \\
\hline $\mathrm{Br}^{-}$ & -58.93 & -58.93 \\
\hline$\left[\mathrm{PtBr}_{3}\left(\mathrm{C}_{2} \mathrm{H}_{4}\right)\right]^{-}$ & -39.51 & -39.01 \\
\hline$\left[\mathrm{PtBr}_{4}\right]^{2-}$ & -149.52 & -148.97 \\
\hline
\end{tabular}

It is first useful to analyze the outcome of the three different approaches to describe the energetic of the ion pair formation. The processes of interest are outlined in equations 1-5 and the results are reported in Table 2 . The $\Delta \mathrm{E}^{\mathrm{CPCM}}$ data show that the association is more 
favourable as expected for the 2:1 salts than for the 1:1 salts. This trend remains valid at the $\Delta \mathrm{G}_{\mathrm{v}}{ }^{\mathrm{CPCM}}$ level. A more detailed analysis reveals an interesting trend. On going from $\Delta \mathrm{E}^{\mathrm{CPCM}}$ to $\Delta \mathrm{G}_{\mathrm{v}}{ }^{\mathrm{CPCM}}$, the difference between them being the $\Delta\left(\mathrm{E}_{\mathrm{ZPVE}}{ }^{\mathrm{gas}}+\mathrm{E}_{\mathrm{v}}{ }^{\mathrm{gas}}-\mathrm{TS}_{\mathrm{v}}{ }_{\mathrm{v}}^{\mathrm{gas}}\right)$ term, the change is very small for the $\mathrm{Br}^{-}$system $\left(-0.6 \mathrm{kcal} \mathrm{mol}^{-1}\right)$, intermediate for the other $1: 1$ salts $(-5.8 \mathrm{kcal}$

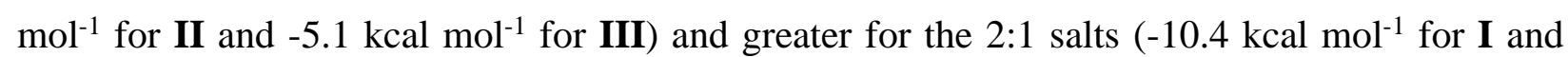
$-13.1 \mathrm{kcal} \mathrm{mol}^{-1}$ for $\left.\mathbf{I}^{\prime}\right)$. The major cause for this trend is the difference of the $\Delta \mathrm{S}_{\mathrm{v}}{ }^{\text {gas }}$ term, which is also reported for convenience in Table 2. All the $\Delta \mathrm{S}_{\mathrm{v}}{ }^{\text {gas }}$ terms are positive, because a number of new low-frequency vibrational modes in the product (related to the relative movement of the cation and anion with respect to each other) are generated from translational and rotational modes in the reagents. For the bromide salt, the separated ions have 9 translational and rotational modes (no rotational modes for the spherical $\mathrm{Br}^{-}$ion), thus only 3 new vibrational modes are generated in the ion pair. For the salts of II and III, both separate ions have 6 non-vibrational modes, thus 6 new vibrational modes result in the product. Finally, for the 2:1 salts of $\mathbf{I}$ and I', the product contains 12 additional vibrational modes relative to the separate ions. Indeed, the value of $\Delta \mathrm{S}_{\mathrm{v}}$ gas is roughly proportional to the number of new vibrational modes. The actual values are of course determined by the frequencies of the new vibrational modes, as well as from the frequency changes in the other modes.

$$
\begin{aligned}
& \mathrm{Br}^{-}+\mathrm{PMe}_{4}^{+} \rightarrow\left(\mathrm{PMe}_{4}\right) \mathrm{Br} \\
& {\left[\mathrm{PtBr}_{4}\right]^{2-}+2 \mathrm{PMe}_{4}^{+} \rightarrow\left(\mathrm{PMe}_{4}\right)_{2}\left[\mathrm{PtBr}_{4}\right]} \\
& \text { I } \quad(\mathrm{TMP})_{2} \mathbf{I} \\
& {\left[\mathrm{Pt}_{2} \mathrm{Br}_{6}\right]^{2-}+2 \mathrm{PMe}_{4}^{+} \rightarrow\left(\mathrm{PMe}_{4}\right)_{2}\left[\mathrm{Pt}_{2} \mathrm{Br}_{6}\right]} \\
& \text { I' } \quad(\mathrm{TMP})_{2} \mathbf{I} \\
& {\left[\mathrm{PtBr}_{3}\left(\mathrm{C}_{2} \mathrm{H}_{4}\right)\right]^{-}+\mathrm{PMe}_{4}^{+} \rightarrow\left(\mathrm{PMe}_{4}\right)\left[\mathrm{PtBr}_{3}\left(\mathrm{C}_{2} \mathrm{H}_{4}\right)\right]} \\
& \text { II (TMP)II } \\
& {\left[\mathrm{PtBr}_{3}\left(\mathrm{PhNH}_{2}\right)\right]^{-}+\mathrm{PMe}_{4}^{+} \rightarrow\left(\mathrm{PMe}_{4}\right)\left[\mathrm{PtBr}_{3}\left(\mathrm{PhNH}_{2}\right)\right]}
\end{aligned}
$$


Table 2. Relative energies changes for the ion pair formations at $298.15 \mathrm{~K}$ in dichloromethane.

\begin{tabular}{|l|c|c|c|c|}
\hline Anionic system & $\Delta \mathrm{E}^{\mathrm{CPCM}}$ & $\Delta \mathrm{G}_{\mathrm{v}}{ }^{\mathrm{CPCM}}$ & $\Delta \mathrm{G}^{\mathrm{CPCM}}$ & $\Delta \mathrm{S}_{\mathrm{v}}{ }^{\text {gas }}$ \\
\hline & $\mathrm{kcal} / \mathrm{mol}$ & $\mathrm{kcal} / \mathrm{mol}$ & $\mathrm{kcal} / \mathrm{mol}$ & e.u. \\
\hline Br- (equation 1) & -8.1 & -8.7 & -2.5 & 8.8 \\
\hline I (equation 2) & -24.5 & -34.9 & -5.9 & 53.2 \\
\hline I' (equation 3) & -18.3 & -31.4 & -0.7 & 65.3 \\
\hline II (equation 4) & -7.2 & -13.0 & 1.5 & 30.4 \\
\hline III (equation 5) & -7.6 & -12.7 & 2.4 & 28.2 \\
\hline
\end{tabular}

On going from $\Delta \mathrm{G}_{\mathrm{v}}{ }^{\mathrm{CPCM}}$ to $\Delta \mathrm{G}^{\mathrm{CPCM}}$, on the other hand, the association becomes nearly ergoneutral for all salts. The major difference between these two parameters corresponds to the $\Delta\left(-\mathrm{TS}_{\text {trans }}{ }^{\text {gas }}-\mathrm{TS}_{\text {rot }}{ }^{\text {gas }}\right)$ term, which is much greater for the $2: 1$ salts $\left(10.2, \mathrm{Br}^{-} ; 18.4, \mathbf{I I} ; 19.1\right.$, III; 37.0, I; 38.7, I'; all values are in $\left.\mathrm{kcal} \mathrm{mol}^{-1}\right)$, plus a smaller term due to $\Delta\left(\mathrm{E}_{\mathrm{tr}}{ }^{\text {gas }}+\mathrm{E}_{\mathrm{rot}}{ }^{\text {gas }}+\mathrm{PV}\right)$. This trend is related to the loss of a greater number of translational and rotational modes in the order $\operatorname{Br}^{-}(3)<$ II,III (6) < I, I'(12).

The question now revolves around which approach yields results in better agreement with the experiment. We do not have quantitative values for the experimental association constants of these salts in dichloromethane, but values for similar salts are available in the literature. For simple bromide salts in dichloromethane, relevant values are $2.5(2) \cdot 10^{4}$ for $n \mathrm{Bu}_{4} \mathrm{NBr}$ [42], 6.6(1) $\cdot 10^{4}$ [42] or $8.0(5) \cdot 10^{4}$ [43] for $\mathrm{Et}_{4} \mathrm{NBr}, 3.9 \cdot 10^{3}$ for $\mathrm{Ph}_{4} \mathrm{AsBr}[44]$ and $1.2 \cdot 10^{3}$ for [PPN]Br [42]. Note the cation dependence, the values of the ammonium salts being greater than those of the bulkier $\mathrm{Ph}_{4} \mathrm{As}^{+}$and $\mathrm{PPN}^{+}$salts. We can predict intermediate values for the $n \mathrm{Bu}_{4} \mathrm{P}^{+}$salt, i.e. $\sim 10^{4}$. For 1:1 salts of similar size to $\mathbf{2}$ and $\mathbf{3}$, relevant values in dichloromethane are $1.94 \cdot 10^{4}$ for $\mathrm{Et}_{4} \mathrm{~N}\left[\mathrm{FeBr}_{4}\right]$ [45], $4.25 \cdot 10^{3}$ for $\mathrm{Ph}_{4} \mathrm{As}_{3}\left[\mathrm{FeBr}_{4}\right]$ [45], 6.8 $10^{4}$ and $1.8 \cdot 10^{4}$ for the $\mathrm{PF}_{6}{ }^{-}$and $\mathrm{BPh}_{4}{ }^{-}$salts of $\left[\mathrm{Pt}(\mathrm{tmda})\left(\mathrm{Me}_{2} \mathrm{SO}\right) \mathrm{Cl}\right]^{+}[46]$, and $3.8(3) \cdot 10^{3}$ for $\left[\mathrm{Cp}^{*}{ }_{2} \mathrm{Fe}\right] \mathrm{PF}_{6}$. The association constants for the $n \mathrm{Bu}_{4} \mathrm{P}^{+}$salts of II and III could also be reasonably estimated as being greater than $10^{3}$. We could not find data for 2:1 salts in dichloromethane. For equilibrium constants of $10^{3}$ and $10^{4}$ at $298 \mathrm{~K}$, the corresponding $\Delta G^{\circ} 298$ is -5.5 and $-4.1 \mathrm{kcal} \mathrm{mol}^{-1}$, respectively. 
Comparison between these $\Delta G$ values and the results in Table 2 shows that, as could be expected, the anticipated experimental results lay in-between the $\Delta G^{\mathrm{CPCM}}$ and $\Delta G_{\mathrm{v}}{ }^{\mathrm{CPCM}}$ values. In other words, a full gas-phase entropy correction overshoots the solution $\Delta G$ value. On the other hand, because of the above discussed transformation of translational and rotational modes into vibrational modes, the vibrational entropy term $\left(-\mathrm{T} \Delta S_{\mathrm{v}}\right)$ yields a negative correction for this particular ion association process, thus the $\Delta \mathrm{E}^{\mathrm{CPCM}}$ values are placed in-between the $\Delta \mathrm{G}_{\mathrm{v}}{ }^{\mathrm{CPCM}}$ and $\Delta \mathrm{G}^{\mathrm{CPCM}}$ values for all salts. These $\Delta E^{\mathrm{CPCM}}$ values appear to be in closer agreement with the expected experimental values than the values of either the $\Delta G_{\mathrm{v}}{ }^{\mathrm{CPCM}}$ of the $\Delta G^{\mathrm{CPCM}}$ approach, at least for the 1:1 salts (TMP)II and (TMP)III. Therefore, use of $\Delta \mathrm{E}^{\mathrm{CPCM}}$ values for the evaluation of ion pairing equilibria, at least for 1:1 salts, should not give results far off reality in general.

\section{(c) Application to the solution equilibria.}

The relative $\Delta \mathrm{G}^{\mathrm{CPCM}}$ values for species I-VIII were already reported and discussed in our previous contribution [13], but no analysis of the corresponding $\Delta \mathrm{E}^{\mathrm{CPCM}}$ and $\Delta \mathrm{G}_{\mathrm{v}}{ }^{\mathrm{CPCM}}$ was offered. For this reason, the complete set of values for these species according to the three models is given in Figure 2 for the dichloromethane solution. The calculation of the energy value in each case takes into account all species consumed and produced starting from the reference system $\mathbf{I}$, as outlined in equations 6-11. The corresponding diagrams in aniline at $25^{\circ}$ and $150^{\circ} \mathrm{C}$ are presented in SI. The data are presented according to the synthetic strategy. Starting from I and I' in the center, addition of ethylene or aniline leads to II (right) and III (left). Then, complex IV, VII and VIII, shown further on the right, are obtained or can be imagined to result from the addition of aniline or ethylene to II, whereas complexes $\mathbf{V}$ and VI, further to the left of $\mathbf{I}$, are obtained by addition of ethylene or aniline to complex III.

$$
2\left[\mathrm{PtBr}_{4}\right]^{2-} \rightarrow\left[\mathrm{Pt}_{2} \mathrm{Br}_{6}\right]^{2-}+2 \mathrm{Br}^{-}
$$




$$
\left[\mathrm{PtBr}_{4}\right]^{2-}+\mathrm{C}_{2} \mathrm{H}_{4} \rightarrow\left[\mathrm{PtBr}_{3}\left(\mathrm{C}_{2} \mathrm{H}_{4}\right)\right]^{-}+\mathrm{Br}^{-}
$$

I

$$
\left[\mathrm{PtBr}_{4}\right]^{2-}+\mathrm{PhNH}_{2} \rightarrow\left[\mathrm{PtBr}_{3}\left(\mathrm{PhNH}_{2}\right)\right]^{-}+\mathrm{Br}^{-}
$$

I

III

$$
\left[\mathrm{PtBr}_{4}\right]^{2-}+\mathrm{C}_{2} \mathrm{H}_{4}+\mathrm{PhNH}_{2} \rightarrow\left[\mathrm{PtBr}_{2}\left(\mathrm{C}_{2} \mathrm{H}_{4}\right)\left(\mathrm{PhNH}_{2}\right)\right]+2 \mathrm{Br}^{-}
$$

I

$$
\mathbf{I V}(\text { trans }), \mathbf{V}(\text { cis })
$$

$\left[\mathrm{PtBr}_{4}\right]^{2-}+2 \mathrm{PhNH}_{2} \rightarrow$ cis- $\left[\mathrm{PtBr}_{2}\left(\mathrm{PhNH}_{2}\right)_{2}\right]+2 \mathrm{Br}^{-}$

I

VI

$\left[\mathrm{PtBr}_{4}\right]^{2-}+2 \mathrm{C}_{2} \mathrm{H}_{4} \rightarrow\left[\mathrm{PtBr}_{2}\left(\mathrm{C}_{2} \mathrm{H}_{4}\right)_{2}\right]+2 \mathrm{Br}^{-}$

I

VII(trans), VIII(cis)

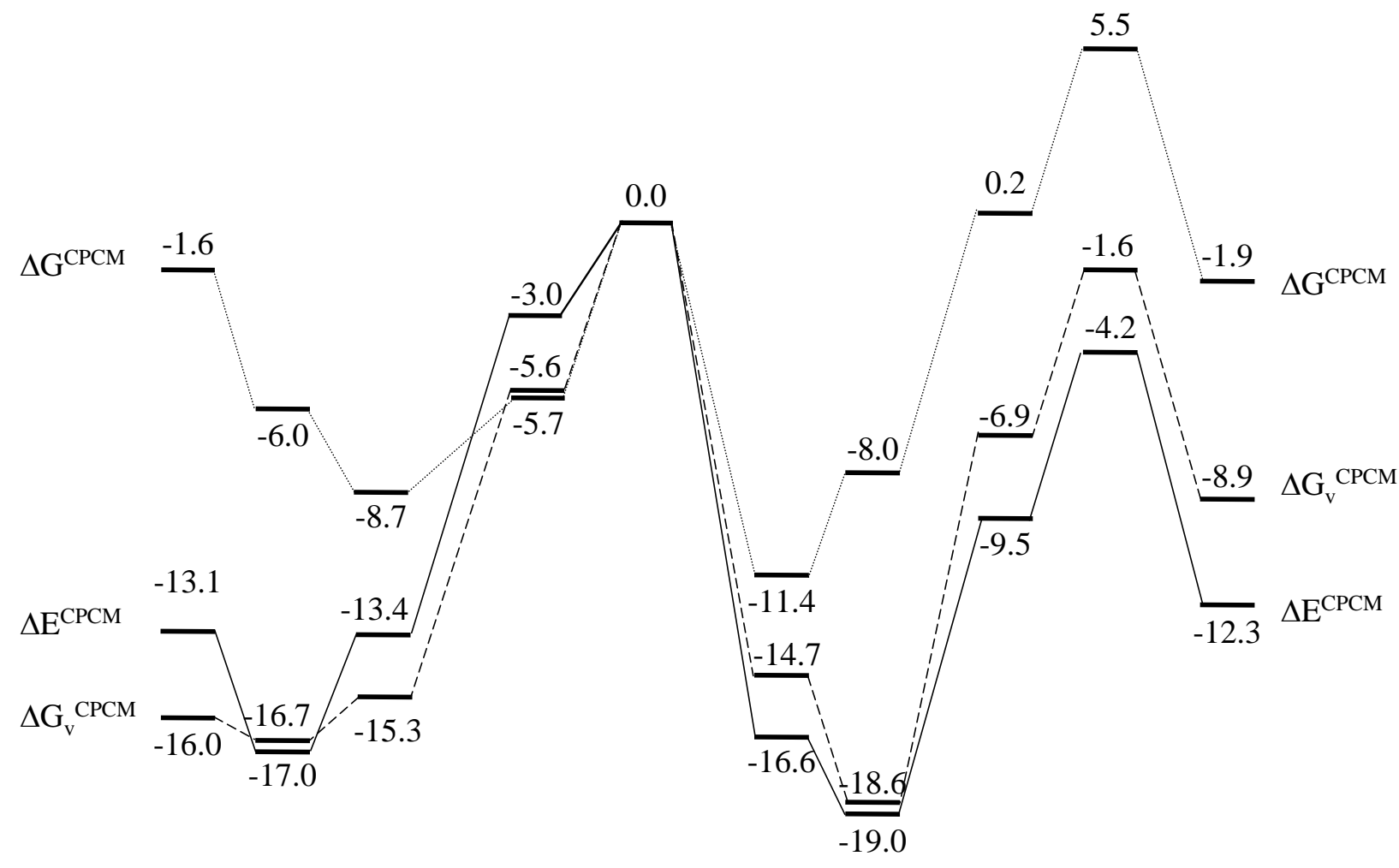

\section{$\begin{array}{llllllllll}\text { VI } & \text { V } & \text { III } & \text { I' } & \text { I } & \text { II } & \text { IV } & \text { VII } & \text { VII' } & \text { VIII }\end{array}$}

Figure 2. Energy diagram for the $\Delta \mathrm{E}^{\mathrm{CPCM}}$ (plain lines), $\Delta \mathrm{G}_{\mathrm{v}}{ }^{\mathrm{CPCM}}$ (dashed lines), and $\Delta \mathrm{G}^{\mathrm{CPCM}}$ (dotted lines) approaches for the anionic model in dichloromethane at $25^{\circ} \mathrm{C}$. All values are reported in $\mathrm{kcal} \mathrm{mol}^{-1}$ relative to I. Species VII' is a different conformer of VII, where one $\mathrm{C}_{2} \mathrm{H}_{4}$ ligand has the C-C axis coplanar with the coordination plane [13]. 
For all complexes, except for $\mathbf{I}^{\prime}, \Delta \mathrm{G}^{\mathrm{CPCM}}>\Delta \mathrm{G}_{\mathrm{v}}{ }^{\mathrm{CPCM}}$ and generally $\Delta \mathrm{G}_{\mathrm{v}}{ }^{\mathrm{CPCM}}>\Delta \mathrm{E}^{\mathrm{CPCM}}$ (except for I', III and VI). The $\Delta \mathrm{G}_{\mathrm{v}}{ }^{\mathrm{CPCM}}$ and $\Delta \mathrm{E}^{\mathrm{CPCM}}$ values are relatively close to each other, whereas $\Delta \mathrm{G}^{\mathrm{CPCM}}$ is significantly greater. This reflects the fact that, for most of the equations 611, $\Delta \mathrm{S}_{\mathrm{v}}{ }^{\text {gas }}$ and $\Delta\left(\mathrm{S}_{\text {trans }}{ }^{\text {gas }}+\mathrm{S}_{\text {rot }}{ }^{\text {gas }}\right)$ are negative and the former is smaller than the latter. The $\Delta\left(\mathrm{E}_{\mathrm{tr}}{ }^{\mathrm{gas}}+\mathrm{E}_{\mathrm{rot}}{ }^{\mathrm{gas}}+\mathrm{PV}\right)$ term gives a zero contribution to all reactions with equal number of species on the reactants and products sides, and the $\Delta \mathrm{E}_{\mathrm{v}}$ gas term is small. Equation 6 , where the molecularity increases, is the only one where both $\Delta\left(\mathrm{S}_{\text {trans }}{ }^{\text {gas }}+\mathrm{S}_{\text {rot }}{ }^{\text {gas }}\right)$ and $\Delta \mathrm{S}_{\mathrm{v}}{ }^{\text {gas }}$ are positive. The same trends are observed in aniline (see SI). The lowest energy species is complex IV according to the $\Delta \mathrm{E}^{\mathrm{CPCM}}$ and $\Delta \mathrm{G}_{\mathrm{v}}{ }^{\mathrm{CPCM}}$ approaches, while complex II is most stable within the $\Delta \mathrm{G}^{\mathrm{CPCM}}$ approach.

The energies differences between different neutral compounds are not affected by the presence of the counterion. Hence, they can already be analyzed on the basis of the results in Figure 2. For instance, for the mixed ligand system $\left[\mathrm{PtBr}_{2}\left(\mathrm{C}_{2} \mathrm{H}_{4}\right)\left(\mathrm{PhNH}_{2}\right)\right]$ the trans isomer has a lower energy than the cis $(\mathbf{I V}<\mathbf{V})$ by $2.0 \mathrm{kcal} \mathrm{mol}^{-1}$ for all energy models. This agrees with the experimental evidence reported in our previous contribution [13]. On the other hand, the cis isomer has a lower energy than the trans for the $\mathrm{PtBr}_{2}\left(\mathrm{C}_{2} \mathrm{H}_{4}\right)_{2}$ system $\left(\right.$ VIII $<$ VII; $2-3 \mathrm{kcal} \mathrm{mol}^{-1}$ depending on the energy model). This is consistent with the experimental evidence reported for the related dichloride system $[15,16]$. The neutral ligand exchange processes leading from the mixed-ligand complexes $\left[\mathrm{PtBr}_{2}\left(\mathrm{C}_{2} \mathrm{H}_{4}\right)\left(\mathrm{PhNH}_{2}\right)\right](\mathbf{I V}$ and $\mathbf{V})$ to the dianiline (VI) or diethylene (VII and VIII) complexes are unfavourable for all energy models. This is again consistent with the experimental evidence, since addition of ethylene to III stops at $\mathbf{V}$ and addition of aniline to II stops at IV. As it can be appreciated, solvation entropy plays a very minor role in these equilibria between neutral species, because the same number of molecules appears on each side. Hence, all approaches reproduce equally well the experiment.

Combination of the ion pairing energies of Table 2 with the relative energies shown in Figure 2 for the solution equilibria of equations 6-11 yields the results summarised in Figure 3 
for dichloromethane at $25^{\circ} \mathrm{C}$, where the system used as reference is (TMP) $)_{2} \mathbf{I}$. The same schemes in aniline solution at $25^{\circ} \mathrm{C}$ and $150^{\circ} \mathrm{C}$ are presented in SI. The processes leading to the species of interest are the same ones already outlined in equations $6-11$, but with all charged species in the associated form with the $\mathrm{PMe}_{4}{ }^{+}$cation.

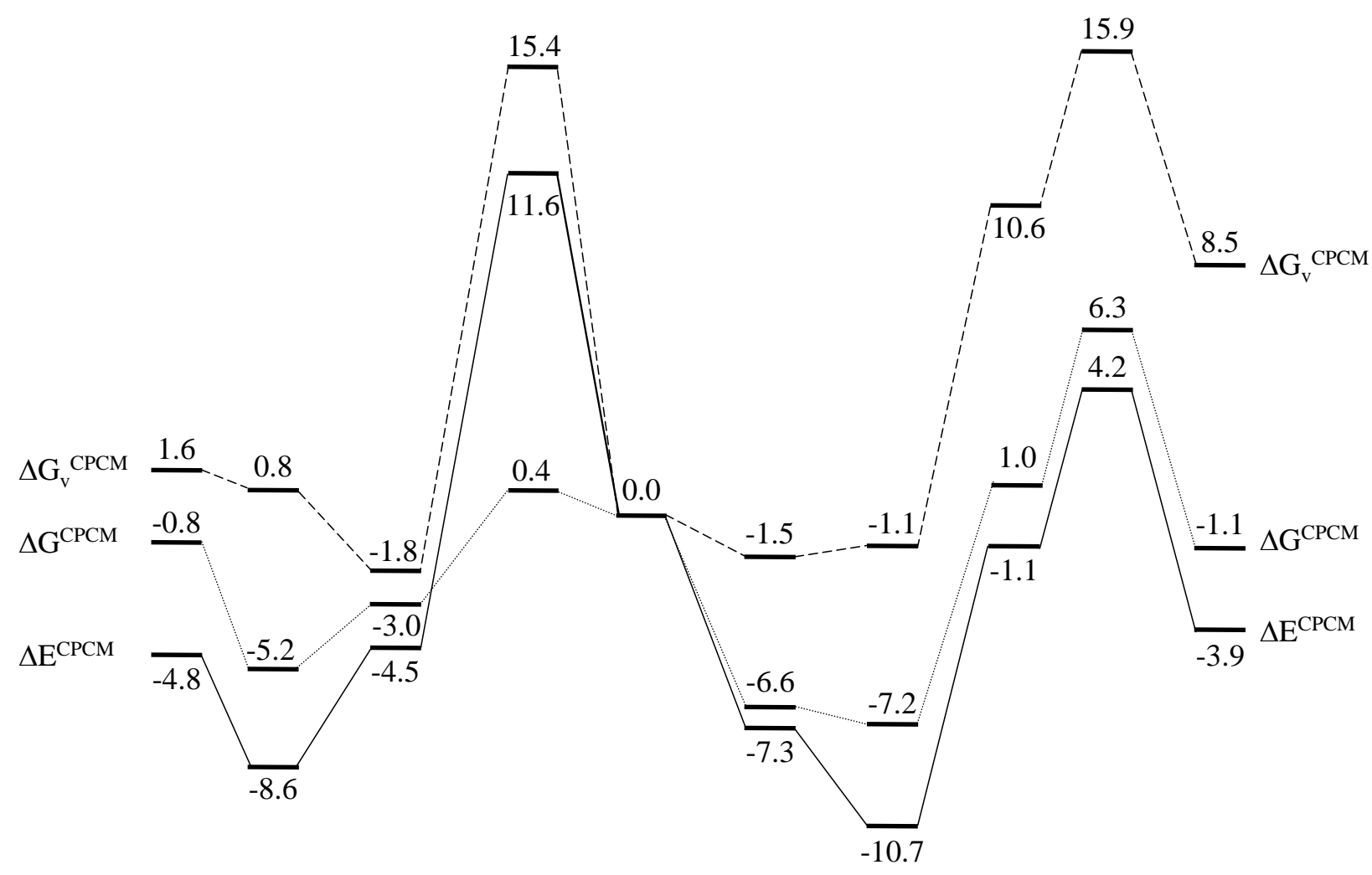

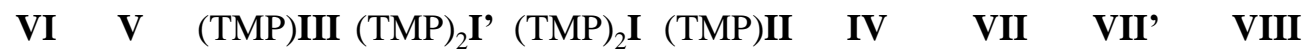

Figure 3. Energy diagram for the $\Delta \mathrm{E}^{\mathrm{CPCM}}$ (plain lines), $\Delta \mathrm{G}_{\mathrm{v}}{ }^{\mathrm{CPCM}}$ (dashed lines), and $\Delta \mathrm{G}^{\mathrm{CPCM}}$ (dotted lines) approaches for the neutral model in dichloromethane at $25^{\circ} \mathrm{C}$. All values are reported in $\mathrm{kcal} \mathrm{mol}^{-1}$ relative to $(\mathrm{TMP})_{2} \mathbf{I}$.

The association of the ionic complexes with the $\mathrm{PMe}_{4}{ }^{+}$cation has a drastic effect on the energy scheme, $c f$. Figure 2 and Figure 3. The ion association process (see Table 2) has the effect of stabilizing all charged species, but the more highly charged species benefit from a greater stabilization. The three monoanionic species (complexes II and III and the $\mathrm{Br}^{-}$ion) are stabilized by approximately the same amount, especially at the $\Delta \mathrm{E}^{\mathrm{CPCM}}$ level, whereas the stabilization of the dianionic complexes is worth more than twice as much on the $\Delta \mathrm{E}^{\mathrm{CPCM}}$ and $\Delta \mathrm{G}_{\mathrm{v}}{ }^{\mathrm{CPCM}}$ scales. 
Therefore, the energy values for all equilibria relating a monoanionic complex with a neutral complex (with release of a $\mathrm{Br}^{-}$ion) are not affected very much, whereas the equilibria relating the doubly charged species I with the singly charged species II and III or with the neutral species are strongly affected by ion pairing at the $\Delta \mathrm{E}^{\mathrm{CPCM}}$ and $\Delta \mathrm{G}_{\mathrm{v}}{ }^{\mathrm{CPCM}}$ levels. On the other hand, the picture changes relatively little at the $\Delta \mathrm{G}^{\mathrm{CPCM}}$ level because the $\Delta \mathrm{G}^{\mathrm{CPCM}}$ values of all ion association equilibria (Table 2) are close to zero. Hence, the relative stabilization of all compounds (except $\mathbf{I}$ ') relative to $\mathbf{I}$ are greatly reduced on the $\Delta \mathrm{E}^{\mathrm{CPCM}}$ and $\Delta \mathrm{G}_{\mathrm{v}}{ }^{\mathrm{CPCM}}$ scales but not as much on the $\Delta \mathrm{G}^{\mathrm{CPCM}}$ scale (cf. Figure 2 and Figure 3) and consequently $\Delta \mathrm{G}_{\mathrm{v}}{ }^{\mathrm{CPCM}}>>$ $\Delta \mathrm{G}^{\mathrm{CPCM}}>\Delta \mathrm{E}^{\mathrm{CPCM}}$ for all compounds, except I', relative to compound (TMP) ${ }_{2} \mathbf{I}$. The process leading from (TMP) $)_{2} \mathbf{I}$ to (TMP) ${ }_{2} \mathbf{I}$ ' transforms two doubly charged species to a new dianionic species and two monoanionic ones. The result is a great destabilization on the $\triangle \mathrm{E}^{\mathrm{CPCM}}$ and $\Delta \mathrm{G}_{\mathrm{v}}{ }^{\mathrm{CPCM}}$ scales.

The ion pair model of Figure 3 entails small qualitative changes relative to the free ion model of Figure 2 concerning the nature of the most stable species in solution: the $\Delta \mathrm{G}^{\mathrm{CPCM}}$ approach now suggests a greater stability for complex IV, whereas it favoured II under the free ion model, while the $\Delta \mathrm{G}_{\mathrm{v}}{ }^{\mathrm{CPCM}}$ approach now slightly favours (TMP)II, whereas it favoured IV under the free ion model. However, the difference between (TMP)II and IV is only $0.6 \mathrm{kcal} / \mathrm{mol}$ in favour of the latter $\left(\Delta G^{\mathrm{CPCM}}\right)$ or $0.4 \mathrm{kcal} / \mathrm{mol}$ in favour of the former $\left(\Delta \mathrm{G}_{\mathrm{v}}{ }^{\mathrm{CPCM}}\right)$. Recall that the experimental studies indicate a greater thermodynamic stability for compound $\mathbf{2}$ (equilibrium 12 is largely shifted to the left). This result would seem better reproduced by the $\Delta G_{\mathrm{v}}{ }^{\mathrm{CPCM}}$ approach for the neutral model and by the $\Delta G^{\mathrm{CPCM}}$ approach for the ionic model.

$$
\left(n \mathrm{Bu}_{4} \mathrm{P}\right)\left[\mathrm{PtBr}_{3}\left(\mathrm{C}_{2} \mathrm{H}_{4}\right)\right]+\mathrm{PhNH}_{2} \rightleftarrows \text { trans- }\left[\mathrm{PtBr}_{2}\left(\mathrm{C}_{2} \mathrm{H}_{4}\right)\left(\mathrm{PhNH}_{2}\right)\right]+\left(n \mathrm{Bu}_{4} \mathrm{P}\right) \mathrm{Br}
$$


It is also useful to recall the other experimental results [13] relating ionic and neutral species, or ionic species of different charge, and compare them with the computational results in Figure 2 and Figure 3. Compound $\mathbf{2}$ is stable relative to $\mathbf{1}$ in the presence of excess $\left(n \mathrm{Bu}_{4} \mathrm{P}\right) \mathrm{Br}$, but a certain amount of $\mathbf{1}$ was generated unless a protected atmosphere of ethylene was present. This suggests that equilibrium 13 is largely shifted to the left hand side, but the free energy difference cannot be more than a few $\mathrm{kcal}^{\mathrm{mol}}{ }^{-1}$. Similarly, equilibrium 14 is also largely shifted toward the left hand side because addition of excess $\left(n \mathrm{Bu}_{4} \mathrm{P}\right) \mathrm{Br}$ to 3 resulted in only minor transformation to $\mathbf{1}$. It is difficult to make estimations because the experimental evidence was only qualitative with no accurate determination of the equilibrium concentrations. However, the large stabilization predicted for II and III relative to I by the ionic model (Figure 2) should lead to no significant formation of $\mathbf{1}$ from either $\mathbf{2}$ or $\mathbf{3}$ under essentially any conditions. The energy differences shown in Figure 3 seem more reasonable, confirming the importance of the cationanion associations in the energy calculations.

$\left(n \mathrm{Bu}_{4} \mathrm{P}\right)\left[\mathrm{PtBr}_{3}\left(\mathrm{C}_{2} \mathrm{H}_{4}\right)\right]+(n \mathrm{Bu} 4 \mathrm{P}) \mathrm{Br} \rightleftharpoons\left(n \mathrm{Bu}_{4} \mathrm{P}\right)_{2}\left[\mathrm{PtBr}_{4}\right]+\mathrm{C}_{2} \mathrm{H}_{4}$

2

$$
\left(n \mathrm{Bu}_{4} \mathrm{P}\right)\left[\mathrm{PtBr}_{3}\left(\mathrm{PhNH}_{2}\right)\right]+\left(n \mathrm{Bu}_{4} \mathrm{P}\right) \mathrm{Br}
$$
3

\section{1}

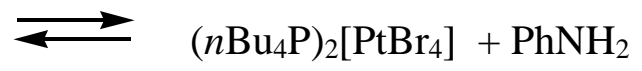

Equilibrium 15 between compounds $\mathbf{2}$ and $\mathbf{5}$ was found displaced toward the left hand side, although the conversion of $\mathbf{5}$ to $\mathbf{2}$ in the presence of a slightly substoichiometric amount of $\left(n \mathrm{Bu}_{4} \mathrm{P}\right) \mathrm{Br}$ did not lead to complete bromide consumption [13] (this study was carried out in DFM due to the insolubility of $\mathbf{5}$ in dichloromethane). Equilibrium 16 between compounds 3 and 6 was also found displaced toward the left hand side, in this case with apparent quantitative conversion of $\mathbf{6}$ to 3 . These results are consistent for the ionic model only under the $\Delta \mathrm{G}^{\mathrm{CPCM}}$ 
approach, whereas the neutral model predicts the correct result for both equilibria under both approaches $\left(\Delta \mathrm{G}^{\mathrm{CPCM}}\right.$ and $\left.\Delta \mathrm{G}_{\mathrm{v}}{ }^{\mathrm{CPCM}}\right)$.

$(n \mathrm{Bu} 4 \mathrm{P})\left[\mathrm{PtBr}_{3}\left(\mathrm{C}_{2} \mathrm{H}_{4}\right)\right]+\mathrm{PhNH}_{2} \rightleftarrows \quad c i s-\left[\mathrm{PtBr}_{2}\left(\mathrm{C}_{2} \mathrm{H}_{4}\right)\left(\mathrm{PhNH}_{2}\right)\right]+(n \mathrm{Bu} 4 \mathrm{P}) \mathrm{Br}$

2

\author{
$\left(n \mathrm{Bu}_{4} \mathrm{P}\right)\left[\mathrm{PtBr}_{3}\left(\mathrm{PhNH}_{2}\right)\right]+\mathrm{PhNH}_{2}$
} 3
5

$\rightleftarrows \quad c i s-\left[\mathrm{PtBr}_{2}\left(\mathrm{PhNH}_{2}\right)_{2}\right]+\left(n \mathrm{Bu}_{4} \mathrm{P}\right) \mathrm{Br}$
6

Finally, equilibrium 17 appears displaced toward the left but not by a large amount, because a small amount of $\mathbf{1}$ ' was spontaneously generated upon prolonged standing from dichloromethane solutions of $\mathbf{1}$ in the absence of free bromide. As shown in Figure 2, the free ion model would predict an essentially quantitative conversion of $\mathbf{1}$ to 1', whereas the ion pair model of Figure 3 can be reconciled with the experiment, under the logical assumption of a partial quenching of the translational and rotational components of the reaction entropy.

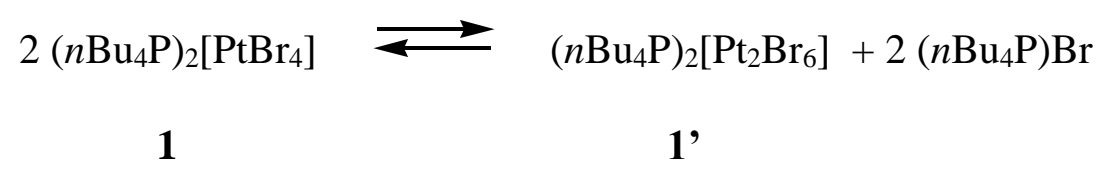

In summary, the utility of the associated salt model is evident for the description of the equilibria involving highly charged species. When only monocharged species are involved, roughly speaking, both the free ion and the ion pair models describe the solution equilibria with acceptable accuracy, but only when the thermochemical parameters (PV and -TS) are introduced to some degree. The $\Delta \mathrm{E}^{\mathrm{CPCM}}$ approach, although apparently the best one to describe the ion association equilibria, does not yield results in agreement with experiment for the ligand exchange equilibria (except for the equilibria relating neutral species). Concerning the best approach for handling the solution entropy problem, conventional wisdom suggests that the real 
solution must lay in-between the $\Delta \mathrm{G}^{\mathrm{CPCM}}$ and $\Delta \mathrm{G}_{\mathrm{v}}{ }^{\mathrm{CPCM}}$ solutions and the qualitative comparison of the computational results according to the ion pair model with the available equilibria shows that this indeed the case. At a very qualitative level, it seems that the experimental result lies closer to the $\Delta \mathrm{G}^{\mathrm{CPCM}}$ prediction than to the $\Delta \mathrm{G}_{\mathrm{v}}{ }^{\mathrm{CPCM}}$ prediction for equilibria involving large changes in charge localization (ion associations for 1:1 salts in Table 2 and equilibrium 17). This amounts to saying that there is no significant quenching of the translational and rotational modes of the various compounds on going from the gas phase to the dichloromethane solution. Otherwise stated, these modes are transformed to very active (low frequency) librations in the solvent cage, greatly contributing to the free energy of the system.

It is not possible to exclude, however, that the shortcoming of various approximations used in the computations lead to systematic errors in favour of $\Delta \mathrm{G}^{\mathrm{CPCM}}$ approach. Amongst these approximations, we can mention the inaccuracy of the harmonic approximation, use of $\mathrm{Me}_{4} \mathrm{P}^{+}$as a model of $n \mathrm{Bu}_{4} \mathrm{P}^{+}$, use of gas-phase optimized rather than solution-phase optimized geometries, and the nature of the functional. However, one additional approximation that might turn out to affect significantly the quality of the calculations is the total neglect of specific interactions (notably hydrogen bonding) between the reagents participating in the considered equilibria with each other and with solvent molecules. For instance, the free aniline and the aniline ligand coordinated to III in equilibrium (8) can serve as proton donors in hydrogen bonding with the bromido ligands of I and III and with the free bromide ion. Similar effects would operate on equilibria 9 and 10.

As a final remark, the investigation of the platinum-catalyzed hydroamination by aniline potentially involves several platinum complexes as intermediates and off-loop species, some of which may be neutral, others anionic. Insofar as these species have a single negative charge, the use of the ionic model seems to provide relevant results, while the participation of doubly charged anions may require a more elaborate study using the associated species. It should be mentioned that other theoretical studies have reported the need to include the counterion. Most 
typically, the counterion in these previous contributions interacts with the catalytic system by coordinating the metal $\left(\right.$ e.g. $\mathrm{F}^{-}$or $\left.\mathrm{Cl}^{-}\right)[47,48]$ or assists intramolecular rearrangement steps $($ e.g. proton transfer by $\left.\mathrm{TfO}^{-}[49]\right)$ and thus changes the nature of the catalytic resting state and/or transition state of the rate determining step. Great attention has been devoted to the control of the structure and relative stability of dormant species and transition states in polymerization catalysis [50-61], while other studies address the orientation or steric influence of the counterion for other types of potential catalytic sites [62-64]. In our case, the $n \mathrm{Bu}_{4} \mathrm{P}^{+}$cation should in principle not play any role other than ion pairing. The explicit effect of the counterion on the relative energetics through cation-anion association equilibria in relation with catalytic processes does not appear to be systematically investigated.

\section{Conclusions}

The availability of solution equilibrium information relating neutral and charged $\mathrm{Pt}^{\mathrm{II}}$ complexes (precatalysts, intermediates or off-loop species for the ethylene hydroamination by aniline) has given us the opportunity to test the accuracy of various energy approaches within the C-PCM model for their description. Consideration of the cation-anion association in the low permittivity dichloromethane and aniline solvents has drastic effect on the energy scheme in comparison to the free ion model, although practically no effect is observed on the geometries and frequencies of the anionic complexes. Consideration of ion pairing is essential for equilibria involving highly charged anionic complexes $(<-1)$, whereas those implicating only neutral and singly charged species are described reasonably well by both the free ion and ion pair models. The most important point is the inadequacy of the common $\Delta \mathrm{E}^{\mathrm{CPCM}}\left(\Delta \mathrm{E}_{\mathrm{el}}^{\mathrm{gas}}+\Delta \Delta \mathrm{G}_{\mathrm{solv}}\right)$ approach, whereas models that introduce the gas phase thermodynamic parameters, $\Delta \mathrm{G}_{\mathrm{v}}{ }^{\mathrm{CPCM}}$ and $\Delta \mathrm{G}^{\mathrm{CPCM}}$,

provide results in better agreement with the experimental results. However, the $\Delta \mathrm{E}^{\mathrm{CPCM}}$ gives better estimates for the solution free energy of the ion pairing process. The correct handling of 
the solute translational and rotational partition function for accurate calculation of solution equilibrium positions is one of the outstanding challenges for computational chemistry. The additional complication of ion pairing equilibria adds another dimension to the complexity of the calculation, but the present contribution shows that relatively significant results can be obtained. We believe that extensive benchmarking using simple ion pairing equilibria that are experimentally well determined at the quantitative level can be of great help for the analysis of the partially quenched translational and rotational motions of solutes.

In terms of our exploration of the $\mathrm{P}^{\mathrm{II}}$-catalyzed hydroamination mechanism and more specifically the investigation of the high-energy portion of the catalytic cycle, the results presented in the present contribution will be of guidance for the selection of the most suitable computational approach. This investigation is currently ongoing and the results will be reported in due course.

Acknowledgement. We thank the CNRS and the RFBR for support through a FranceRussia (RFBR - CNRS) bilateral grant № 08-03-92506, and the MENESR (Ministère de l'Éducation nationale de l'enseignement supérieur et de la recherche de France) for the Ph.D. fellowship to P.A.D.

[1] J. J. Brunet, M. Cadena, N. C. Chu, O. Diallo, K. Jacob, E. Mothes, Organometallics 23 (2004) 1264-1268.

[2] J. J. Brunet, N. C. Chu, O. Diallo, Organometallics 24 (2005) 3104-3110.

[3] M. Rodriguez-Zubiri, S. Anguille, J.-J. Brunet, J. Mol. Catal. A 271 (2007) 145-150.

[4] J.-J. Brunet, N.-C. Chu, M. Rodriguez-Zubiri, Eur. J. Inorg. Chem. (2007) 4711-4722.

[5] H. M. Senn, P. E. Blochl, A. Togni, J. Am. Chem. Soc. 122 (2000) 4098-4107.

[6] R. Palumbo, A. De Renzi, A. Panunzi, G. Paiaro, J. Am. Chem. Soc. 91 (1969) 38743879.

[7] A. Panunzi, A. De Renzi, R. Palumbo, G. Paiaro, J. Amer. Chem. Soc. 91 (1969) 38793883.

[8] A. Panunzi, A. Derenzi, G. Paiaro, J. Am. Chem. Soc. 92 (1970) 3488-3489.

[9] E. Benedetti, A. De Renzi, G. Paiaro, A. Panunzi, C. Pedone, Gazz. Chim. Ital. 102 (1972) 744-754.

[10] D. Hollings, M. Green, D. V. Claridge, J. Organometal. Chem. 54 (1973) 399-402.

[11] T. E. Muller, M. Beller, Chemical Reviews 98 (1998) 675-703.

[12] T. E. Müller, K. C. Hultzsch, M. Yus, F. Foubelo, M. Tada, Chem. Rev. 108 (2008) 3795-3892. 
[13] P. A. Dub, M. Rodriguez-Zubiri, J.-C. Daran, J.-J. Brunet, R. Poli, Organometallics 28 (2009) 4764-4777.

[14] J. Chatt, R. G. Wilkins, Nature (London, U. K.) 165 (1950) 859-860.

[15] M. R. Plutino, S. Otto, A. Roodt, L. I. Elding, Inorg. Chem. 38 (1999) 1233-1238.

[16] S. Otto, A. Roodt, L. I. Elding, Inorg. Chem. Commun. 9 (2006) 764-766.

[17] V. Barone, M. Cossi, J. Phys. Chem. A 102 (1998) 1995-2001.

[18] M. Cossi, N. Rega, G. Scalmani, V. Barone, J. Comput. Chem. 24 (2003) 669-681.

[19] A. A. C. Braga, G. Ujaque, F. Maseras, Organometallics 25 (2006) 3647-3658.

[20] C. E. Chang, W. Chen, M. K. Gilson, J. Chem. Theory Comput. 1 (2005) 1017-1028.

[21] J. Carlsson, J. Aqvist, Journal of Physical Chemistry B 109 (2005) 6448-6456.

[22] N. Singh, A. Warshel, Journal of Physical Chemistry B 113 (2009) 7372-7382.

[23] M. Sumimoto, N. Iwane, T. Takahama, S. Sakaki, J. Am. Chem. Soc. 126 (2004) 1045710471.

[24] G. W. T. M. J. Frisch, H. B. Schlegel, G. E. Scuseria, M. A. Robb, J. R. Cheeseman, J. Montgomery, J. A., T. Vreven, K. N. Kudin, J. C. Burant, J. M. Millam, S. S. Iyengar, J. Tomasi, V. Barone, B. Mennucci, M. Cossi, G. Scalmani, N. Rega, G. A. Petersson, H. Nakatsuji, M. Hada, M. Ehara, K. Toyota, R. Fukuda, J. Hasegawa, M. Ishida, T. Nakajima, Y. Honda, O. Kitao, H. Nakai, M. Klene, X. Li, J. E. Knox, H. P. Hratchian, J. B. Cross, C. Adamo, J. Jaramillo, R. Gomperts, R. E. Stratmann, O. Yazyev, A. J. Austin, R. Cammi, C. Pomelli, J. W. Ochterski, P. Y. Ayala, K. Morokuma, G. A. Voth, P. Salvador, J. J. Dannenberg, V. G. Zakrzewski, S. Dapprich, A. D. Daniels, M. C. Strain, O. Farkas, D. K. Malick, A. D. Rabuck, K. Raghavachari, J. B. Foresman, J. V. Ortiz, Q. Cui, A. G. Baboul, S. Clifford, J. Cioslowski, B. B. Stefanov, G. Liu, A. Liashenko, P. Piskorz, I. Komaromi, R. L. Martin, D. J. Fox, T. Keith, M. A. Al-Laham, C. Y. Peng, A. Nanayakkara, M. Challacombe, P. M. W. Gill, B. Johnson, W. Chen, M. W. Wong, C. Gonzalez, J. A. Pople, Gaussian 03, Revision C.02, Gaussian, Inc., Wallingford CT (2004).

[25] A. D. Becke, J. Chem. Phys. 98 (1993) 5648-5652.

[26] C. T. Lee, W. T. Yang, R. G. Parr, Phys. Rev. B 37 (1988) 785-789.

[27] B. Miehlich, A. Savin, H. Stoll, H. Preuss, Chem. Phys. Lett. 157 (1989) 200-206.

[28] Y. Zhao, D. G. Truhlar, Acc. Chem. Res. 41 (2008) 157-167.

[29] L. E. Roy, P. J. Hay, R. L. Martin, J. Chem. Theory Comput. 4 (2008) 1029-1031.

[30] J. W. Ochterski, http://www.gaussian.com/g_whitepap/thermo.htm (2000).

[31] Y. Takano, K. N. Houk, J. Chem. Theory Comput. 1 (2005) 70-77.

[32] A. Klamt, B. Mennucci, J. Tomasi, V. Barone, C. Curutchet, M. Orozco, F. J. Luque, Acc. Chem. Res. 42 (2009) 489-492.

[33] J. M. Ho, M. L. Coote, Theor. Chem. Acc. 125 (2010) 3-21.

[34] E. Cances, B. Mennucci, J. Tomasi, J. Chem. Phys. 107 (1997) 3032-3041.

[35] B. Mennucci, J. Tomasi, J. Chem. Phys. 106 (1997) 5151-5158.

[36] B. Mennucci, E. Cances, J. Tomasi, Journal of Physical Chemistry B 101 (1997) 1050610517.

[37] M. Cossi, V. Barone, B. Mennucci, J. Tomasi, Chem. Phys. Lett. 286 (1998) 253-260.

[38] J. Tomasi, B. Mennucci, E. Cances, J. Mol. Struct. Theochem. 464 (1999) 211-226.

[39] P. Winget, C. J. Cramer, D. G. Truhlar, Theor. Chem. Acc. 112 (2004) 217-227.

[40] M. Montejo, F. P. Urena, F. Marquez, A. M. Ingrain, J. J. L. Gonzalez, J. Raman. Spectrosc. 39 (2008) 460-467.

[41] P. A. Dub, N. V. Belkova, O. A. Filippov, J.-C. Daran, L. M. Epstein, A. Lledós, E. S. Shubina, R. Poli, Chem. Eur. J. 16 (2010) 189-201.

[42] I. Svorstol, H. Hoiland, J. Songstad, Acta Chemica Scandinavica Series B-Organic Chemistry and Biochemistry 38 (1984) 885-893.

[43] S. Balt, G. Duchattel, W. Dekieviet, A. Tieleman, Z. Naturforsch. Sect. B 33 (1978) 745749. 
[44] J. A. Labinger, J. A. Osborn, N. J. Coville, Inorg. Chem. 19 (1980) 3236-3243.

[45] G. P. Algra, S. Balt, Inorg. Chem. 20 (1981) 1102-1106.

[46] G. Alibrandi, R. Romeo, L. M. Scolaro, M. L. Tobe, Inorg. Chem. 31 (1992) 5061-5066.

[47] J. M. Fraile, J. I. Garcia, M. J. Gil, V. Martinez-Merino, J. A. Mayoral, L. Salvatella, Chem. Eur. J. 10 (2004) 758-765.

[48] T. Hatakeyama, S. Hashimoto, K. Ishizuka, M. Nakamura, J. Am. Chem. Soc. 131 (2009) 11949-11963.

[49] G. Kovacs, G. Ujaque, A. Lledos, J. Am. Chem. Soc. 130 (2008) 853-864.

[50] M. S. W. Chan, K. Vanka, C. C. Pye, T. Ziegler, Organometallics 18 (1999) 4624-4636.

[51] D. Braga, F. Grepioni, E. Tedesco, M. J. Calhorda, Z. Anorg. Allg. Chem. 626 (2000) 462-470.

[52] I. E. Nifant'ev, L. Y. Ustynyuk, D. N. Laikov, Organometallics 20 (2001) 5375-5393.

[53] P. G. Belelli, M. M. Branda, N. J. Castellani, J. Mol. Catal. A 192 (2003) 9-24.

[54] I. E. Nifant'ev, L. Y. Ustynyuk, D. V. Besedin, Organometallics 22 (2003) 2619-2629.

[55] E. Zurek, T. Ziegler, Prog. Polym. Sci. 29 (2004) 107-148.

[56] T. Ziegler, K. Vanka, Z. T. Xu, C. R. Chimie 8 (2005) 1552-1565.

[57] S. H. Yang, J. Huh, W. H. Jo, Macromolecules 38 (2005) 1402-1409.

[58] J. M. Ducere, L. Cavallo, Organometallics 25 (2006) 1431-1433.

[59] P. G. Belelli, N. J. Castellani, J. Mol. Catal. A 253 (2006) 52-61.

[60] T. A. Manz, S. Sharma, K. Phomphrai, K. A. Novstrup, A. E. Fenwick, P. E. Fanwick, G. A. Medvedev, M. M. Abu-Omar, W. N. Delgass, K. T. Thomson, J. M. Caruthers, Organometallics 27 (2008) 5504-5520.

[61] S. Tomasi, A. Razavi, T. Ziegler, Organometallics 28 (2009) 2609-2618.

[62] J. R. Miecznikowski, S. Grundemann, M. Albrecht, C. Megret, E. Clot, J. W. Faller, O. Eisenstein, R. H. Crabtree, Dalton Trans. (2003) 831-838.

[63] L. R. Moore, E. C. Western, R. Craciun, J. M. Spruell, D. A. Dixon, K. P. O'halloran, K. H. Shaughnessy, Organometallics 27 (2008) 576-593.

[64] D. Zuccaccia, L. Belpassi, F. Tarantelli, A. Macchioni, J. Am. Chem. Soc. 131 (2009) 3170-3171. 
Graphics for the Table of Contents

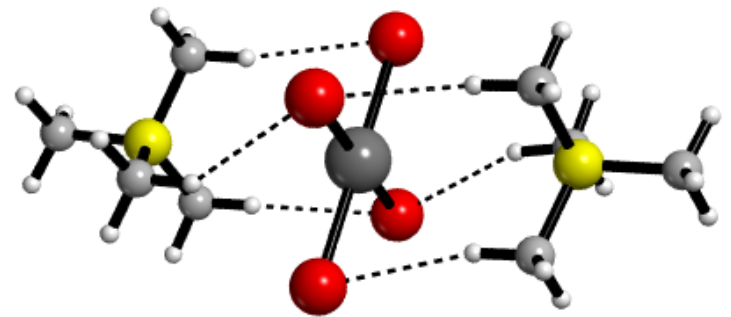

